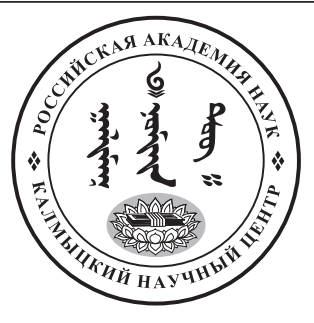

Published in the Russian Federation

Oriental Studies (Previous Name: Bulletin of the Kalmyk Institute

for Humanities of the Russian Academy of Sciences)

Has been issued as a journal since 2008

ISSN: 2619-0990; E-ISSN: 2619-1008

Vol. 13, Is. 6, pp. 1641-1651, 2020

DOI: $10.22162 / 2619-0990-2020-52-6-1641-1651$

Journal homepage: https://kigiran.elpub.ru

УДК 294.3+003.335

DOI: 10.22162/2619-0990-2020-52-6-1641-1651

\title{
Гадание по нагару лампады
}

\section{Бембя Леонидович Митруев ${ }^{1}$}

${ }^{1}$ Калмыцкий научный центр РАН (д. 8, ул. им. И. К. Илишкина, 358000 Элиста, Российская Федерация) научный сотрудник

iD 0000-0002-1129-9656. E-mail: bemitrouev@yahoo.com

(C) КалмНЦ РАН, 2020

(C) Митруев Б. Л., 2020

Аннотация. Введение. Гадание по нагару лампады было распространено среди множества других видов гаданий в Тибете, Монголии, Калмыкии и других регионах. Цель статьи ввести в научный оборот тексты такого гадания на китайском, тибетском и монгольском языках. Анализ этого гадания проливает свет на ценности, логику, символизм и структуру традиционного общества. Материальl. В статье использован материал из разных источников. Китайский текст гадания взят из китайской публикации, изданной в Хух-хото Цзинь Сюй Чжэньжэнем. Тибетский текст - с сайта Центра буддийских цифровых ресурсов (Buddhist Digital Resource Center). Пекинский ксилограф монгольского текста данного гадания хранится в монгольском фонде Института восточных рукописей РАН. Он был сверен с другой копией пекинского ксилографа, полученной от преподавателя кафедры философии и религиоведения Национального университета Монголии Дэмбэрэла Сухээ. Результаты. В статье проанализирован традиционный способ гадания по нагару лампады и проведено сравнительное исследование текстов на трех языках, представлены перевод и транслитерация китайского, тибетского и монгольского текстов гадания.

Ключевые слова: гадание, лампада, нагар, китайский, тибетский, монгольский

Благодарность. Исследование проведено в рамках государственной субсидии - проект «Устное и письменное наследие монгольских народов России, Монголии и Китая: трансграничные традиции и взаимодействия» (номер госрегистрации: АААA-А19-119011490036-1). Автор выражает благодарность А. М. Ятри и А. А. Сизовой за помощь в подготовке статьи, Дэмбэрэлу Сухээ — за возможность ознакомиться с рукописью.

Для цитирования: Митруев Б. Л. Гадание по нагару лампады // Oriental Studies. 2020. T. 13. № 6. C. 1641-1651. DOI: 10.22162/2619-0990-2020-52-6-1641-1651 
UDC $294.3+003.335$

DOI: $10.22162 / 2619-0990-2020-52-6-1641-1651$

\title{
Oil Lamp Snuff Divination
}

\author{
Bembya L. Mitruev ${ }^{1}$
}

${ }^{1}$ Kalmyk Scientific Center of the RAS (8, Ilishkin St., Elista 358000, Russian Federation) Research Associate

iD 0000-0002-1129-9656. E-mail: bemitrouev@yahoo.com

(C) KalmSC RAS, 2020

(C) Mitruev B. L., 2020

\begin{abstract}
Introduction. Oil lamp snuff divination practices used to be widespread enough in Tibet, Mongolia, Kalmykia, and other regions. Goals. The paper introduces into scientific discourse texts thereof in Chinese, Tibetan, and Mongolian. The analysis of the practices reveals values, logic, symbols, and structural patterns inherent to traditional societies. Materials. The article examines a number of sources, namely: 1) a Chinese text published in Hohhot (Inner Mongolia, PRC), 2) a Tibetan text posted on the website of Buddhist Digital Resource Center, 3) a Beijing xylograph of one Mongolian text stored at the Institute of Oriental Manuscripts of the RAS (St. Petersburg, Russia). The latter was checked against another copy of the Beijing xylograph submitted by Demberel Sükhee, a lecturer at the National University of Mongolia (Department of Philosophy and Religious Studies). Results. The article analyzes the traditional oil lamp snuff divination method and provides a comparative study of texts in three different languages, translating and transliterating the employed sources.
\end{abstract}

Keywords: divination, oil lamp, snuff, Chinese, Tibetan, Mongolian

Acknowledgements. The reported study was funded by government subsidy — project name 'Oral and Written Heritage of Mongolic Peoples of Russia, Mongolia and China: Cross-Border Traditions and Interactions' (state reg. no. AAAA-A19-119011490036-1). The author expresses gratitude to А. М. Yatri и А. A. Sizova for their assistance, to Demberel Sukhee for his permission to investigate the manuscript.

For citation: Mitruev B. L. Oil Lamp Snuff Divination. Oriental Studies. 2020. Vol. 13(6): 1641-1651. (In Russ.). DOI: 10.22162/2619-0990-2020-52-6-1641-1651

\section{है}

\section{Введение}

Среди текстов по лампадомансии или гадания на светильнике существует китайский текст гадания, в котором описывается гадание, где главным объектом исследования является не само пламя, а нагар, образующийся на фитиле во время горения. Этот вид гадания практиковался в Китае, а затем получил распространение в Тибете, Монголии и Калмыкии. Свидетельством бытования данного вида гадания в Калмыкии является информация от жителя Калмыкии Г. Б. Корнеева, получившего от X. О. Бембеева ${ }^{1}$ копию ойратского текста данного гадания, переложение которого с ойратского «ясного письма» на калмыцкий язык было опубликовано на сайте «Центра по развитию калмыцкого языка» в статье, озаглавленной «Гадания по пламени лампадки» ${ }^{2}$. К сожалению, нам не удалось получить копию

\footnotetext{
${ }^{1}$ Сведения получены во время личной беседы.

${ }^{2}$ См.: Корнеев Г. Б. Гадание по пламени лампадки [электронный ресурс] // URL: http://baylig. $\mathrm{ru} / \mathrm{p}=878$ (дата обращения: 27.11.2020).
} 
ойратского текста для данного исследования.

Традиционные китайские гадания, среди них и гадание на нагаре, описаны Ричардом Смитом [Smith 1986]. Внимательное отношение к предзнаменованиям было широко распространено в традиционном Китае, особенно среди верхушки общества, где легитимность императоров и династий зависели от небесного мандата (t'ien-ming). Благоприятные знаки (fu-jui, hsiang-jui и т. д.), такие как появление цветных испарений, яркого света, редких животных, необычных растений, странных камней, сладкой росы и т. д., как считалось, отражали удовлетворенность небес и предвещали радостные события; тогда как бедствия (tsai-i), такие как непредвиденные затмения и подобные небесные аномалии, землетрясения, наводнения и другие стихийные бедствия, указывали на недовольство небес и, возможно, даже на утрату мандата. На популярном уровне эти предзнаменования также воспринимались всерьез, наряду с менее драматическими признаками, такими как крики птиц (niao-chiao), нагар или форма фитиля лампады (teng-hua) и различные телесные ощущения (зуд, покалывание, чихание и т. д.) [Smith 1986: 166].

В традиционных обществах для гадания часто использовали те предметы, которые широко применялись в быту. Примером подобного гадания может быть гадание по нагару лампады. С распространением буддизма в Китае, Тибете и Монголии масляная лампада стала неотъемлемой частью быта жителей этих регионов. Лампада была практически в каждом доме и также стала предметом для гадания. Нагар на фитиле лампады на китайском языке обозначается словом дэнхуа (кит. dēnghuā; 灯花), где dēng - 'лампа, фонарь, светильник', а первое значение слова huā - 'цветок', что дало начало переводу на тибетский и монгольский языки китайского слова «нагар» как «цветок лампады» (тиб. mar me'i me tog) или просто «цветок» (тиб. me tog; монг. с̌еčeg).

Цель статьи - ввести в научный оборот тексты гадания по нагару лампады на китайском, тибетском и монгольском языках.

\section{Тексты}

Китайский текст гадания является частью текста, известного как «Нефритовая шкатулка», и был издан в Хух-хото Цзинь Сюй Чжэньжэнем (кит. jìn хǔ zhēnrén; 晋许 真人) в книге «,,Записи нефритовой шкатулки ${ }^{е}$. Исправленное и дополненное издание» (кит. shùjù zēngbǔ yùxiá jì; 数据 增补玉匣记) [Сюй 2010]. Подробно об этом тексте и его истории можно узнать из статьи «О фрагменте монгольского перевода „Заново переведенных 'Записей нефритовой шкатулки' для разных деле из Национального музея имени Алдан Маадыр Республики Тыва» [Митруев 2019].

Тибетский текст, привлеченный к анализу в настоящей работе, находится на сайте Центра буддийских цифровых ресурсов ${ }^{3}$, он озаглавлен «[Раздел] Те. Исследование нагара на лампаде» (тиб. te / mar me'i me tog brtags pa), входит в издание Института Дзигар другпа кагью (Zigar Drugpa Kagyu Institute) 1975 г., носящее название «Записи „Нефритовая шкатулка ${ }^{\text {eе }}$ (тиб. brjed tho g.yang ti'i za ma tog) [g.yang ti'i za ma tog 1975]. Это издание в свою очередь представляет собой репродукцию с пекинского ксилографа, опубликованного Обществом восстановления буддийской литературы двадцати пяти центров медитации (тиб. sgom sde nyer lnga'i gsung rabs nyams gso lhag blo mthun tshogs). Автором ошибочно указан Юй Ся Цзи (тиб. yus-syAi-kyi). Юй Ся Цзи, без сомнения, является транскрипцией китайского названия этого текста yu xia ji «Записи нефритовой шкатулки». В колофоне отсутствует имя автора и переводчика. Пагинация дана в соответствии с номерами страниц, данными арабскими цифрами на левом поле издания Института Дзигар другпа кагью.

Монгольский текст «Исследования лампады» (монг. zul šinjikü) представлен по ксилографическому изданию šine orčula ssan

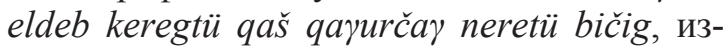
данному в Пекине (Пекинский ксил., тетрадь, 136 л.) [МФ ИВР РАН. F-145]. Шифр F 145, инв. № 1677 [Сазыкин 1988: 312].

3 Buddhist Digital Resource Center [электронный ресурс] // URL: https://www. tbrc.org/\#library_work_ViewInWIndowW2 $7507 \% 7 C 4476 \% 7 C 1 \% 7 C 1 \% 7 C 1 \% 7 C 362$ (дата обращения: 20.11.2020). 
Более подробно издания и рукописи данного текста описаны в вышеупомянутой статье о фрагменте монгольского перевода «Заново переведенных „Записей нефритовой шкатулки“ для разных дел» [Митруев 2019]. Текст из Института восточных рукописей РАН (далее - ИВР РАН) был сверен с другой копией пекинского ксилографа, полученной от преподавателя кафедры философии и религиоведения Национального университета Монголии Дэмбэрэла Сухээ. К сожалению, полученная копия была не очень высокого качества, поэтому главным образом мы опираемся на ксилографическое издание из ИВР РАН. Пагинация дана в соответствии с китайской пагинацией на маргиналиях пекинского ксилографа. Так как в китайском издании номер присваивается всему листу, который затем складывается вдвое и сшивается переплетом, левой стороне листа был присвоено обозначение «a», а правой стороне - обозначение «b».

\section{Тибетские тексты}

Помимо рассматриваемого здесь гадания по нагару лампады, в тибетской традиции существует несколько других текстов по лампадомансии или гадания по пламени, которые включают в себя наблюдение за нагаром светильника. Все эти тексты довольно сильно отличаются от рассматриваемого. Мы представим здесь три таких текста.

Первым из этих трех текстов является терма ${ }^{4}$, открытое тертоном ${ }^{5}$ Сангьелингпой (тиб. sangs rgyas gling pa; 1340

${ }^{3}$ Терма (тиб. gter ma). По-тибетски «сокрытые сокровища» или «текст-сокровище», источник священных предметов тибетского буддизма и религии бон, включающий в себя широкий спектр рукописей, реликвий, скульптур и ритуальных принадлежностей более ранних периодов. Такие тексты-сокровища находили в пещеpax, горах, озерах, долинах или обнаруживались в монастырях, иногда внутри колонн и прочего [PDB 2014: 329].

5 Тертон (тиб. gter ston) - букв. «открыватель сокровищ», человек, который обнаруживает терма или «сокровище» - священные предметы тибетского буддизма и религии бон, включая широкий спектр рукописей, реликвий, скульптур и ритуальных принадлежностей, которые предположительно были спрятаны в более ранние периоды, чтобы быть открытыми в более поздний период времени [PDB 2014: 329].
1396), под названием «Исследование ясного света лампады „Пылающий свете» (тиб. bla ma dgongs pa 'dus pa las snang gsal mar me'i brtag pa 'od 'bar zhe bya ba), опубликованное в 42 томе из 70 томов «Сокровищницы драгоценных откровений» (тиб. rin chen gter mdzod) в монастыре Шечен (тиб. zhe chen) [Сангье-лингпа 2007-2008: 968-971]. Краткое изложение этого гадания представлено в книге «Оракулы и предсказания» [Loewe, Blacker, Lama Chime Radha 1981: 19-20]. Отличие этого текста от рассматриваемого в данном исследовании заключается в том, что в гадании исследуется не нагар, а само пламя и фитиль, а также звуки, запахи и прочее, возникающие при горении пламени лампады.

Автором другого текста по названием «Исследование лампады» является известный тибетский ученый Джу Мипам Гьяцо ('ju mi pham rgya mtsho; 1846-1912), это сочинение находится в 29 томе изданного в Ченду «Обществом быстрого сохранения старых текстов тибетской культуры» (тиб. gangs can rig gzhung dpe rnying myur skyobs lhan tshogs) его 32-томного собрания сочинений [Джу Мипам Гьяцо 2007: 561-569]. Этот текст основывается, как сказано в колофоне, на предыдущем тексте терма Сангье-лингпы, исследованиях из тантр и устных наставлений и «Кратком исследовании лампады», переведенном Барилоцавой (тиб. ba ri lo ts A ba; 1040-1111). По всей видимости, автор был знаком с китайской традицией исследования лампадного нагара, так как он пишет, что китайцы считают образование нагара хорошим знаком. В этом сочинении рассматривается пламя, фитиль, звуки, запахи и нагар лампады, а также содержатся иллюстрации.

Третье сочинение представляет собой тайные или, как сказано в колофоне, «запечатанные устные наставления» (тиб. gdams ngag bka' rgya ma) Дармо-менрампы (тиб. dar mo sman rams pa). По всей видимости, этот автор - не кто иной, как врач Пятого Далай-ламы Дармо-менрампа Лобсанг Чойдраг (тиб. dar mo sman rams pa blo bzang chos grags; 1638-1710). Этот текст назван «Метод исследования лампады» (тиб. mar me'i brtag thabs) и опубликован в книге «Трактат об украшениях и музыкальных инструментах тантрической традиции старых переводов» (тиб. gsang rnying rgyan dang rol 
mo’i bstan bcos) [Метод исследования лампады 1996: 333-336]. Данный трактат главным образом сосредотачивает свое внимание на пламени лампады.

\section{Китайское гадание и его переводы}

Интересно отметить, что в этом гадании нет обращения к божествам, буддам или каким-либо другим силам, что может указывать на небуддийский характер этого гадания. Возможно, лампада подносилась в храме пред божествами или изображениями духов предков с надеждой, что они посредством нагара на фитиле укажут исход важных для просителя дел. Рождение сына, обретение богатства и получение известий было важным для всех членов общества. По всей видимости, погодные условия были важны для земледельцев, ожидающих урожая, а продвижение по чиновничьей лестнице и повышение жалования было важно для чиновников. В гаданиях глава семьи центральное лицо, на которое «действуют» все общие предсказания. Если для главы семьи выпадает какое-то предсказание, то оно автоматически распространяется на остальных домочадцев. Возможно, поэтому в тибетском тексте термин «хозяин» часто опущен, так как подразумевается, что действие предсказания распространяется на всех вокруг него.

При сравнении переводов заметно, что они различаются по длине. Тибетский перевод выполнен по более полному варианту китайского текста, который сейчас нам не доступен. Этот тибетский перевод довольно близко следует китайскому оригиналу, лишь иногда упрощая и несколько по-другому интерпретируя текст. В китайском тексте недостает последней части с предсказаниями о погоде, хотя о них говорится в начале текста. Монгольский текст переведен с китайского с применением приема симплификации или упрощения переводимого материала. Некоторые части текста сокращены и перемещены в другую часть текста, так, например, первые два абзаца китайского оригинала, в которых даются общие сведения о лампаде и говорится том, как необходимо обращаться с лампадой, в монгольском тексте перенесены в самый конец. Таким образом, китайскому отрывку: «Возможно, что [лампада] — источник света в темном доме. Нельзя сбивать и крошить [нагар], образующийся на всех лампадах, подобных другим на алтаре», соответствует находящийся в другой части текста монгольский текст: «Возможно, что [лампада] - источник света в темном доме. Нельзя сбивать и крошить [нагар], образующийся на всех лампадах, подобных другим на алтаре».

Текст монгольского ксилографа, по всей видимости, выполнялся по дефектной копии монгольского текста, содержащей ошибки. Поэтому монгольская фраза busu metü ajuqu, на наш взгляд, скорее всего, представляет собой неверное прочтение графически схожего по написанию глагола boyomdalaqu 'ставить преграду' (боомтлох (bgomdeleee) 'ставить преграду' [БАМРС 2001: 261]) или в данном случае 'препятствовать'. Случаи неправильного прочтения были нередки в монгольских переводах. Один из таких случаев в тексте «Заново переведенных ,Записей нефритовой шкатулки“ для разных дел» описан в нашей статье [Митруев 2019: 759-760].

В таком прочтении смысл последнего абзаца становится яснее и ближе к китайскому оригиналу: «Нельзя препятствовать [горению] лампады на алтаре, сбивать и крошить [нагар], образующийся на всех лампа-

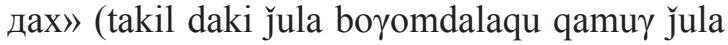
čečelge üu šiden abasu: oүtačiǰu abubasu ülü bolumui:).

В некоторых местах объяснения к разным предсказаниям объединены в одном предсказании, например, два отдельных элемента в китайском тексте: «Если лампада сама собой погасла, у хозяина будет траур. Если снял возникший нагар и задул пламя, это предвещает унизительную неприятность», в монгольском тексте сокращены и объединены в один: «Если [пламя] беспричинно поднялось вверх и погасло, будут смерть, горе, несчастье и дурные знаки».

О том, что тибетский перевод этого труда был известен в Монголии и имел там хождение, свидетельствует рукопись на тибетском языке из Национальной библиотеки Монголии, под шифром М0059752, хранящаяся на сайте Центра буддийских цифровых ресурсов ('Buddhist Digital Resource Center'). Текст находится на 243-246 страницах в подборке разрозненных текстов на тибетском языке, озаглавленной «Черный 
сборник "Шкатулка из драгоценности чинтамани, исполняющей желания" и прочие сочинения» (тиб. be'u bum nag po 'dod pa'i re skong tsin+ta ma Ni' i za ma tog sogs) [Черный сборник]. В начале текста помещен тибетский слог «ТЕ», обозначающий порядковый номер этого текста в сборнике «Нефритовая шкатулка».

\section{Заключение}

Исходя из приведенных здесь текстов, с уверенностью можно сказать, что гадание на нагаре лампады имеет небуддийский характер; некогда существовала более полная версия китайского текста, с которой был выполнен перевод на тибетский; монгольский перевод был сделан с китайского варианта, близкого или совпадающего с тем, что представлен в данной работе. Из приведенных переводов становится очевидно, что и в случае с тибетским, и в случае с монгольским переводами текст гадания был упрощен для облегчения понимания читателем. Из-за невозможности точной датировки китайского текста гадания остается неясной история развития и распространения этого гадания в Тибете и Монголии. Также неясно, оказала ли тибетская традиция исследования лампады, представленная, например, упомянутым выше текстом Сангье-лингпы, на китайскую или нет. Из колофона к тексту Джу Мипама, цитируемому выше, становится ясно, что существовала и индийская традиция лампадомансии, один из текстов которой был переведён Бари-лоцавой.

Мы хотели бы подчеркнуть важность исследования подобного рода гадательных практик, приведя слова американского ученого историка Ричарда Смита: «Другими словами, я предполагаю, что анализ китайского гадания прольет ценный свет не только на ценности, логику, символизм и структуру традиционного китайского общества, но также на концепции космологии и причинности, а также на вопросы личной и политической власти, социальный порядок и социальные конфликты. Таким образом, как акт интерпретации, гадание „раскрывается“" в нескольких отношениях» [Smith 1986: 153-154].

\section{Перевод}

\begin{tabular}{|c|c|c|}
\hline Перевод тибетского текста & Перевод китайского текста & $\begin{array}{l}\text { Перевод монгольского } \\
\text { текста }\end{array}$ \\
\hline $\begin{array}{l}\text { [233] Раздел «ТЕ» } \\
\text { Метод исследования «цветка» лам- } \\
\text { пады следующий: } \\
\text { вследствие того, что лампада осве- } \\
\text { щает дом и [ее] цветок вместе с пе- } \\
\text { стиком испускают лучи света, мож- } \\
\text { но узнать плохое и хорошее о доме, а } \\
\text { также облачно небо или ясно. }\end{array}$ & $\begin{array}{l}\text { [185] Лампада - главный } \\
\text { источник отражения [собы- } \\
\text { тий] для всего дома, по тому, } \\
\text { как она разгорается, дает за- } \\
\text { вязь вместе с тычинкой }{ }^{5} \text {, ис- } \\
\text { пускает свет и пламя, можно } \\
\text { узнать об удаче и несчастье } \\
\text { людей. Можно узнать, бу- } \\
\text { дет ли погода солнечная или } \\
\text { дождливая. }\end{array}$ & \\
\hline $\begin{array}{l}\text { Если на [фитиле] лампады собирает- } \\
\text { ся нагар, оставь его, не колебля. Не } \\
\text { дуй на него. }\end{array}$ & $\begin{array}{l}\text { Когда лампада разгорается, } \\
\text { позволь [пламени] пребы- } \\
\text { вать естественным образом. } \\
\text { Нельзя ворошить его, гасить, } \\
\text { задувать и разжигать снова. }\end{array}$ & \\
\hline $\begin{array}{l}\text { Если нагар образовался и долго не } \\
\text { падает, [234] на следующий день бу- } \\
\text { дет благополучие. }\end{array}$ & $\begin{array}{l}\text { Если нагар образовался и дол- } \\
\text { го не падает, завтра хозяина } \\
\text { ждет радостное событие. }\end{array}$ & $\begin{array}{l}\text { [46а] Исследование лам- } \\
\text { пады следующее: если [на } \\
\text { фитиле] образуется нагар } \\
\text { и долго не падает, хозяин } \\
\text { [дома] будет радостен. }\end{array}$ \\
\hline
\end{tabular}

${ }^{6}$ Возможно, здесь имеется в виду, как огонь соединяется с фитилем. 


\begin{tabular}{|c|c|c|}
\hline $\begin{array}{l}\text { Если [нагар] не упал до рассвета, в } \\
\text { течение пяти дней будут благие со- } \\
\text { бытия. }\end{array}$ & $\begin{array}{l}\text { Если [нагар] не упал до рас- } \\
\text { света, в течение пяти дней } \\
\text { непрерывно будут счастливые } \\
\text { события. }\end{array}$ & $\begin{array}{l}\text { Если [нагар] также не упал } \\
\text { до рассвета, пять дней, не } \\
\text { прекращаясь, будет радость. }\end{array}$ \\
\hline $\begin{array}{l}\text { Если нагар указывает вовне, от боль- } \\
\text { шого человека обязательно будет из- } \\
\text { вестие. }\end{array}$ & $\begin{array}{l}\text { [186] Если нагар указывает } \\
\text { вовне, то обязательно придет } \\
\text { письмо от высокопоставлен- } \\
\text { ного человека. }\end{array}$ & $\begin{array}{l}\text { [46b] Если нагар указыва- } \\
\text { ет вперед, то от большого } \\
\text { человека обязательно будет } \\
\text { письмо. }\end{array}$ \\
\hline $\begin{array}{l}\text { Если так происходит в течение семи } \\
\text { дней, получишь повышение и обре- } \\
\text { тешь пищу и одежду. Сам везде най- } \\
\text { дешь скот и пахотную землю. }\end{array}$ & $\begin{array}{l}\text { Если так происходит в тече- } \\
\text { ние семи ночей, чиновник } \\
\text { получит продвижение и по- } \\
\text { вышение должности. Рядовой } \\
\text { человек разбогатеет, будет } \\
\text { жить в довольствии, земля и } \\
\text { имущество будут в достатке. }\end{array}$ & $\begin{array}{l}\text { Если так происходит в тече- } \\
\text { ние семи дней, ранг и жало- } \\
\text { ванье сановника увеличатся. } \\
\text { Удача и благополучие про- } \\
\text { столюдина умножатся. }\end{array}$ \\
\hline $\begin{array}{l}\text { Если язычок пламени внезапно } \\
\text { разделился надвое, получишь } \\
\text { милость, обретешь повышение, } \\
\text { будут благополучие и счастье. } \\
\text { Высокопоставленный человек даст } \\
\text { протекцию. }\end{array}$ & $\begin{array}{l}\text { Если язычок пламени вне- } \\
\text { запно раздвоился, хозяину } \\
\text { предвещает великую милость, } \\
\text { вскоре будет пожаловано по- } \\
\text { вышение, будут радостные } \\
\text { события. Образованный че- } \\
\text { ловек получит высокий чин и } \\
\text { поддержку знатных людей. }\end{array}$ & $\begin{array}{l}\text { Если язычок пламени } \\
\text { раздвоился, [будет] большая } \\
\text { радость, ранг и жалованье } \\
\text { увеличатся. }\end{array}$ \\
\hline $\begin{array}{l}\text { Если ожерелье нагара висит вниз, это } \\
\text { предвещает далёкое путешествие. }\end{array}$ & $\begin{array}{l}\text { Если нагар свисает вниз, } \\
\text { хозяину предстоит далёкое } \\
\text { путешествие. }\end{array}$ & $\begin{array}{l}\text { Если нагар висит ровно, } \\
\text { словно четки, хозяин дома } \\
\text { отправится в далёкое путе- } \\
\text { шествие. }\end{array}$ \\
\hline $\begin{array}{l}\text { Если посреди языков пламени по- } \\
\text { явился нагар, [похожий] на зеленую } \\
\text { горошину, это предвещает обретение } \\
\text { еды и питья. Также это предрекает } \\
\text { рождение хорошего сына. }\end{array}$ & $\begin{array}{l}\text { Если нагар в центре похож на } \\
\text { фасолину, это означает, что у } \\
\text { хозяина будет застолье, а бе- } \\
\text { ременная [жена] родит сына. }\end{array}$ & $\begin{array}{l}\text { Если нагар похож на горо- } \\
\text { шину, то будет вино, а также } \\
\text { родится превосходный сын. }\end{array}$ \\
\hline $\begin{array}{l}\text { Если появился нагар [235] вместе } \\
\text { с искрами, будет благополучие и } \\
\text { повышение должности. }\end{array}$ & $\begin{array}{l}\text { Если нагар постепенно рас- } \\
\text { сыпается, хозяина ждет ра- } \\
\text { достное событие, [он будет] } \\
\text { выбран и повышен по долж- } \\
\text { ности, будет празднество. }\end{array}$ & $\begin{array}{l}\text { Если нагар в несколько сло- } \\
\text { ев, будет благополучие и } \\
\text { повышение по должности и } \\
\text { великая радость. }\end{array}$ \\
\hline $\begin{array}{l}\text { Если нагар смотрит вверх и образует } \\
\text { большую сферу, это предвещает } \\
\text { прибытие известия на следующий } \\
\text { день. }\end{array}$ & $\begin{array}{l}\text { Если нагар направлен вверх } \\
\text { и круглой формы, это предве- } \\
\text { щает прибытие завтра гостя. }\end{array}$ & $\begin{array}{l}\text { Если нагар высокий и } \\
\text { большой круглой формы, } \\
\text { завтра обязательно прибудет } \\
\text { гость. }\end{array}$ \\
\hline $\begin{array}{l}\text { Если языки пламени внезапно } \\
\text { прояснились и проливают свет } \\
\text { наружу, это предвещает прибытие } \\
\text { гостя издалека. }\end{array}$ & $\begin{array}{l}\text { Если лампада сама по себе } \\
\text { ярко разгорелась, это предве- } \\
\text { щает прибытие письма изда- } \\
\text { лека. }\end{array}$ & $\begin{array}{l}\text { [47a] Если [лампада] вне- } \\
\text { запно с тресканьем излучи- } \\
\text { ла свет, издалека прибудут } \\
\text { письмо и новости. }\end{array}$ \\
\hline $\begin{array}{l}\text { Если лампада беспричинно погасла, } \\
\text { это предзнаменование смерти или } \\
\text { горя. }\end{array}$ & $\begin{array}{l}\text { Если лампада сама } \\
\text { погасла, у хой } \\
\text { траур. }\end{array}$ & $\begin{array}{l}\text { Если [пламя] беспричинно } \\
\text { поднялось вверх и погасло, } \\
\text { будут смерть, горе, несчастье } \\
\text { и дурные знаки. }\end{array}$ \\
\hline
\end{tabular}




\begin{tabular}{|l|l|l|}
\hline $\begin{array}{l}\text { Если снял возникший нагар и задул } \\
\text { пламя, нсли снял возникший нагар и } \\
\text { события, вызывающие стыд. }\end{array}$ & $\begin{array}{l}\text { Возможно, что [лампада] } \\
\text { - источник света в темном } \\
\text { задул пламя, это предвещает } \\
\text { унизительную неприятность. }\end{array}$ & $\begin{array}{c}\text { доме. Нельзя сбивать и кро- } \\
\text { шить [нагар], образующийся } \\
\text { на всех лампадах, подобных } \\
\text { другим на алтаре. }\end{array}$ \\
\hline $\begin{array}{l}\text { Если нагар образовался на [фитиле] } \\
\text { лампады во время долгого дождя и } \\
\text { его цвет прекрасен, на следующий } \\
\text { день небо прояснится. Если языки } \\
\text { пламени распространяются над ды- } \\
\text { мом, а сами языки пламени красные, } \\
\text { неясные и висят вниз, [236], то на } \\
\text { следующий день пойдет дождь. Если } \\
\text { дыма нет, а языки пламени колышат- } \\
\text { ся влево и вправо, на следующий } \\
\text { день поднимется сильный ветер. } \\
\text { Если же языки пламени неподвижны } \\
\text { и ясны, на следующий день погода } \\
\text { будет ясной. Если дым черный, света } \\
\text { мало, а [пламя] неподвижно, будет } \\
\text { ясная, но ветреная погода. Когда в } \\
\text { течение долгого времени стоит за- } \\
\text { суха и вершина пламени коротка, а } \\
\text { языки пламени небольшие, в течение } \\
\text { трех дней пойдет дождь. }\end{array}$ & \\
\end{tabular}

\section{Китайский текст}

[185] 占灯花法

灯乃一家鉴照之主, 开花、结孶、吐焰、生光, 知人间之吉凶, 识天时之晴雨。凡 灯有花, 任其自开自谢, 不可挑剔、剪火, 一吹灭, 不可再吹。灯有花, 久不灭, 来日 主有喜庆，至天明不灭不绝，五日内喜

[186] 事不绝。开花向外, 必于大人处得书, 乃七夜如此。仕人则加官进禄, 爵位高 迁, 常人则生财纳福, 田产立至。焰忽两分, 主有大恩, 即授迁官, 吉庆。士人则有 大官委命及贵人引援。灯花连珠下垂者, 主有远行。灯中心结花如灯豆, 主有酒食, 孕 生贵子。灯花连连逐出爆者, 主大喜, 选举迁官升, 吉庆。灯花向上圆大者, 主明日 有客至。灯自明而炸者, 主远信至。灯自灭者, 主丧服。灯若有花忽挑者、吹灭者, 主有耻辱之事。

\section{Транслитерация тибетского текста}

[233] te /

mar me'i me tog brtags pa ni/ mar me khyim gsal bar byed cing me tog ge sar bcas 'od zer 'phro bas/ khyim gyi legs nyes dang / gnam gyi 'thib dwangs shes nus/ mar me la me tog thog tshe mi bsgul bar 'jog/ phu 'debs mi bya/ me tog thog ste yun ring ma lhung na

[234] phyi nyin bkra shis pa'i bya ba 'byung / nam lang bar du ma brul na nyi ma lnga'i nang du bya ba bzang po rgyun du 'byung / me tog phyir bstan na nges par mi chen nas 'phrin 'byung / nyi ma bdun la 'di ltar byung na/ go sa "phar cing zas gos 'thob/ rang ga pa yang nor zhing rnyed/ me lce glo bur du gnyis su phye na bka' drin 'thob go sa 'phar bkra shis shing bde legs su 'gyur/ mi chen gyis mgo 'dren byed/ me tog 'brel ma thur du 'phyang na thag ring gi mgron yong ba'i ngo / me lce'i nang du me tog sran ljang 'dra ba byung na bza' btung rnyed pa'i ngo / bu bzang po skye ba'i ngo / me tog

[235] me stag sgra bcas byung na bkra shis go sa "phar/ me tog kha steng du bltas shing gormochebabyungnaphyinyin 'phrinyong ba'ingo/melcebloburgsalcing 'odphyir' gyedbabyung 
nathag ring gimgronyong ba'ingo/marmerkyen med parshina 'chiba' ammyangan gyingo/metog chags pa blangs ste phu rgyab nas bsad na phyi nyin ngo tsha ba'i bya ba 'byung / char ba yun ring 'bab bzhin pa'i dus su mar me la me tog chags cing mdangs legs na phyi nyin gnam thangs par 'gyur/ du ba'i steng du me lce mched cing / me lce dmar po mi gsal ba thur du 'phyang ba

[236] byung na phyi nyin char ba 'babs/ du ba med cing melce dmarpo g.yas g.yon du g.yo na phyi nyin rlung chen ldang / me lce mi g.yo zhing gsal na phyi nyin thangs par 'gyur/ du ba nag cing 'od cung zad dang bcas mi g.yo na gnam thang la rlung 'byung / than pa yun ring byung skabs rtse mo thung la me lce chung ngu mched na nyi ma gsum gyi nang du char ba 'byung /

\section{Транслитерация монгольского текста}

[46a] zul šinjikü anu: čečeglejü öni ese untarbal eǰen anu bayasqulang bolumui: ür čayital-a basa ülü untarbal: tabun edür bayar ülü tasuran:

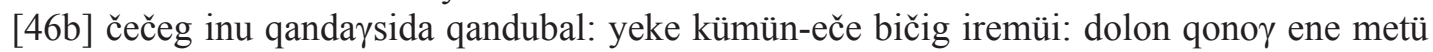
bolbal-a noyan kümün kergem punglu nemekü: eng-ün kümün kišig buyan nemekeü: dölün inu qoyar anggi qayarbal: yeke bayar ǰerge kergim [=kergem] nemedeg [:] čečeg inu erikelen unǰibal: ger-ün ejen qola qajar yabumui [:] čečeg inu burča metü bolbala ariki ba manglai kübün törömüi [:] čečeg inu dabqur dabqur bolbal-a: jerge debšin yeke bayar bolumui [:] čečeg inu öndör yeke

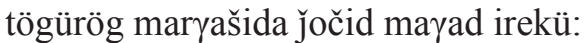

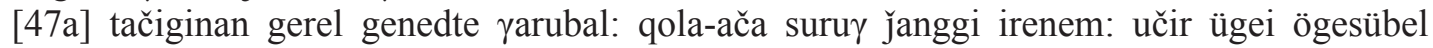

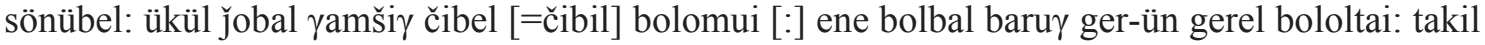

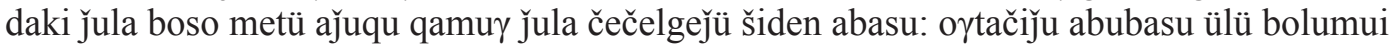

\begin{abstract}
Источники
Метод исследования лампады - Метод исследования лампады (mar me'i brtag thabs) // gsang rnying rgyan dang rol mo'i bstan bcos (= Трактат об украшениях и музыкальных инструментах тантрической традиции старых переводов). Lhasa: bod ljongs bod yig dpe rnying dpe skrun khang, 1996 [= Лхаса: Тибетское издательство древних книг на тибетском языке, 1996]. 377 p. Vol. 1 Pp. 181-182 [электронный ресурс] // URL: https://www. tbrc.org/\#library_work_ViewByOutlineO1GS584671GS58480\%7CW22300 (дата обращения: 27.11.2020).
\end{abstract}

МФ ИВР РАН- Монгольский фонд Отдела рукописей и документов Института восточных рукописей РАН (г. Санкт-Петербург).

МФ ИВР РАН. F-145 - šine orčulaysan eldeb

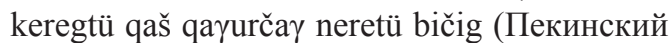
ксил., тетрадь, 136 л.). Шифр F-145, инв. № 1677.

БАМРС 2001 - Большой академический монгольско-русский словарь в четырёх томах / под общ. ред. Лувсандэндэва А., Цэдэндамба Ц., отв. ред. Г. Ц. Пюрбеев. В 4 тт. Т. 1. А-Г. М.: Academia, 2001. 485 c.

Джу Мипам Гьяцо 2007 - Джу Мипам Гьяцо. Исследование лампады ('ju mi pham rgya mtsho. mar me brtag pa). mi pham bka' 'bum. Chengdu: gangs can rig gzhung dpe rny- ing myur skyobs lhan tshogs. 2007. 710 p. Vol. 29. Рp. 561-569. [электронный ресурс] // URL: https://www.tbrc.org/\#library_work_ ViewByOutline-O1PD451591PD453802DB6 47192DB647201PD657111PD657411PD6574 71PD65749\%7CW2DB16631 (дата обращения: 24.10.2020).

Черный сборник — «Черный сборник „Шкатулка из драгоценности чинтамани, исполняющей желания““ и прочие сочинения» (тиб. be'u bum nag po 'dod pa'i re skong tsin+ta ma Ni’i za ma tog sogs) [электронный ресурс] // URL: https://www.tbrc.org/\#library_work_ ViewInWIndow-W1NLM1834\%7CI1NLM1 34_001\%7C1\%7C1\%7C1\%7C270 (дата обращения: 15.10.2020).

g.yang ti'i za ma tog 1975 - Записи «Нефритовая шкатулка» (brjed tho g.yang ti'i za ma tog). Rewalsar: Zigar Drugpa Kagyu Institute, 1975. 351 с. [электронный ресурc] // URL: https://www.tbrc. org/\#library_work_View In W Indow W27507\%7C4476\%7C1\%7C1\%7C1\%7C362 (дата обращения: 20.11.2020).

Loewe, Blacker, Lama Chime Radha 1981 Loewe M., Blacker C. (eds), with contr. by Lama Chime Radha, Rinpoche et al. Divination and oracles. London; Boston: Allen \& Unwin, 1981. 244 p., [10] p. of plates: ill. 
Сангье-лингпа 2007-2008 - Сангье-лингпа. Исследование ясного света лампады «Пылающий свет» (sangs rgyas gling pa. bla ma dgongs pa 'dus pa las snang gsal mar me'i brtag pa 'od 'bar zhe bya ba). rin chen gter mdzod. Vol. 42. New Delhi: Shechen

\section{Sources}

be'u bum nag po 'dod pa'i re skong tsin+ta ma Ni'i za ma tog sogs: A Black Collection Compiled from 'The Casket of Chintamani, a WishFulfilling Jewel' and Other Texts. Available at: https://www.tbrc.org/\#library_work ViewInWIndow-W1NLM1834\%7CI1NLM18 34_001\%7C1\%7C1\%7C1\%7C270 (accessed: October 15, 2020). (In Tib.)

brjed tho g.yang ti'i za ma tog: The Jade Casket. Rewalsar: Zigar Drugpa Kagyu Institute, 1975. 351 p. Available at: https://www. tbrc.org/\#library_work_ViewInWIndowW27507\%7C4476\%7C1\%7C1\%7C1\%7C362 (accessed: November 20, 2020). (In Tib.)

gsang rnying rgyan dang rol mo'i bstan bcos: The Treatise about Decorative Elements and Musical Instruments in the Tantric Tradition of Old Translations. Lhasa: Tibetan Publ. House of Ancient Tibetan Books, 1996. 377 p. Vol. 1. Pp. 181-182. Available at: https:// www.tbrc.org/\#library_work_ViewByOutlineO 1 GS 584671 GS $58480 \% 7$ CW 22300 (accessed: November 27, 2020). (In Tib.)

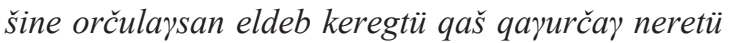
bičig. Xylograph. Beijing edition. At: Institute of Oriental Manuscripts of the RAS (St. Petersburg), Department of Manuscripts and

\section{Литература}

Митруев 2019 - Митруев Б. Л. О фрагменте монгольского перевода «Заново переведенных „Записей нефритовой шкатулки“ для разных дел» из Национального музея имени Алдан Маадыр Республики Тыва // Монголоведение. 2019. № 4. С. 751-813. DOI: $10.22162 / 2500-1523-2019-4-751-813$

Сазыкин 1988 - Сазыкин А. Г. Каталог монгольских рукописей и ксилографов Института востоковедения Академии наук СССР. Т. I. М.: Наука, 1988. 508 с.

Сюй 2010 - Сюй Чжэньжэнь. «Записи publications. 2007-2008. 1061 с. [электронный ресурc] // URL: https://www. tbrc.org/\#library_work_ViewByOutlineO4CZ3373954CZ352918\%7CW1KG14 (дата обращения: 20.10.2020).

Documents, Mongolian Collection. Call no. F-145. Item 1677. 136 p. (In Mong.)

Ju Mipham Gyatso. Examining an Oil Lamp. In: Mi pham bka' 'bum. Chengdu, 2007. Vol. 29. Pp. 561-569. Available at: https://www.tbrc. org/\#library_work_ViewByOutline-O1PD4515 91PD453802DB647192DB647201PD657111P D657411PD657471PD65749\%7CW2DB16631 (accessed: October 24, 2020). (In Tib.)

Sangye Lingpa. bla ma dgongs pa 'dus pa las snang gsal mar me'i brtag pa 'od 'bar zhe bya ba: A Treatise on Examining the Lucid Light of an Oil Lamp Titled 'The Flaming Light'. Ser.: Rin chen gter mdzod. Vol. 42. New Delhi: Shechen Publications, 2007-2008. 1061 p. Available at: https:// www.tbrc.org/\#library_work_ViewByOutlineO4CZ3373954CZ352918\%7CW 1 KG 14 (accessed: October 20, 2020). (In Tib.)

Loewe M., Blacker C. (eds.), with contr. by Lama Chime Radha, Rinpoche et al. Divination and Oracles. London; Boston: Allen \& Unwin, 1981. 244 p., [10] p. of plates: ill. (In Eng.)

Pyurbeev G. Ts., Luvsandendev A., Tsedendamba Ts. (eds.) Unabridged Academic Mongolian-Russian Dictionary. In 4 vols. Vol. 1: А-Г. Moscow: Academia, 2001. 485 p. (In Mong. and Russ.)

Нефритовой Шкатулки». Исправленное и дополненное издание (Zengbu Yu Xia Ji). Хуххото: Народное издательство Внутренней Монголии, 2010. 244 с. (на кит. яз.)

Smith 1986 - Smith Richard J. «Knowing Fate»: Divination in Late Imperial China // American Association of Chinese Studies. Journal of Chinese Studies. Hong-Kong. 1986. October. Vol. 3. No. 2. Pp. 153-190.

PDB 2014 - Princeton Dictionary of Buddhism. Robert E. Buswell Jr., Donald S. Lopez Jr. Princeton: Princeton University Press, 2014. $1304 \mathrm{p}$. 


\section{References}

Buswell R. E. Jr., Lopez D. S. Jr. Princeton Dictionary of Buddhism. Princeton: Princeton University Press, 2014. 1304 p. (In Eng.)

Mitruev B. L. 'The Jade Box Writings Newly Translated for Various Occasions': a fragment of one Mongolian translation from the Aldan Maadyr National Museum of the Tyva Republic revisited. Mongolian Studies. 2019. No. 4. Pp. 751-813. (In Russ.) DOI: 10.22162/25001523-2019-4-751-813
Sazykin A. G. Institute of Oriental Studies, USSR Academy of Sciences: Catalogue of Mongolian Manuscripts and Xylographs. Vol. I. Moscow: Nauka, 1988. 508 p. (In Russ.)

Smith R. J. 'Knowing fate': divination in late imperial China. American Journal of Chinese Studies. 1986, October. Vol. 3. No. 2. Pp. 153190. (In Eng.)

$\mathrm{Xu}$ Shenzhen. The Jade Box Writings. Rev. and Suppl. Hohhot: Inner Mongolia People's Publ. House, 2010. 244 p. (In Chin.) 